\title{
Analisa Kinerja Struktur Beton Bertulang Pasca Kebakaran
}

\author{
Abdullah Latip ${ }^{1, a}$ \\ ${ }^{1}$ Dosen, Jurusan Sipil PNUP, Jalan Perintis Kemerdekaan Km. 10 Tamalanrea, Makassar, 90245, Indonesia \\ a latip-uh03@poliupg.ac.id
}

\begin{abstract}
This Paper aims to analyze the performance level of Pasar Butung post-fire on December 15, 2010. The fire was centered on the 1st and 2nd floor. Data retrieval include visual observation, carbonation test, concrete hammer test, concrete core test and tensile test of steel reinforcement that was held on January, 2011. All data that was taken will use to analyze the structure. Observations indicate that the temperature of the fire around $400^{\circ} \mathrm{C}$. Beams and columns on floors 1 and 2 had cracks and the quality of concrete fell $62 \%$ from $21.15 \mathrm{MPa}$ to $14 \mathrm{MPa}$ at the outer cross-section. While the floor plates 2 and 3 having $a$ width of cracks and residual concrete quality is only 11.57 MPa. Pushover analysis (static lateral load) is a nonlinear static analysis that can provide detailed information about the collapse behavior of structures against earthquake loads, while the performance point is the magnitude of the maximum displacement of the structure during an earthquake plan. Results of $3 D$ nonlinear static pushover analysis on the structure of Pasar Butung shows that performance point is achieved when the base reaction $V$ reach 484.97 tons with displacement of $0.021 \mathrm{~m}(2.1 \mathrm{~cm})$ at step 3. Results of analysis showed that the performance of the structure is still within the limits of Life Safety
\end{abstract}

Keywords; Pasar Butung post-fire; Field Observation;Pushover; Life Safety

Abstrak-Pada tanggal 15 Desember 2010 telah terjadi kebakaran di Pasar Butung Makassar. Kebakaran tersebut berpusat di lantai 1 dan 2. Tulisan ini bertujuan untuk menganalisis kinerja struktur Pasar Butung pasca kebakaran. Pengambilan data meliputi pengamatan visual, pengujian karbonasi, pengujian alat palu beton, pengujian beton inti dan pengujian kuat tarik baja tulangan. Hasil pengamatan menunjukkan bahwa temperatur kebakaran sekitar $400^{\circ} \mathrm{C}$. Balok dan kolom pada lantai 1 dan 2 mengalami retak rambut dan mutu beton turun $62 \%$ dari 21,15 MPa menjadi 14 MPa pada bagian luar penampang. Sedangkan pelat lantai 2 dan 3 mengalami retak yang lebar dan mutu beton sisa hanya 11,57 Mpa. Analisa pushover (beban dorong statik) adalah analisa statik nonlinier yang dapat memberikan informasi yang detail mengenai perilaku keruntuhan struktur terhadap beban gempa, sedangkan titik kinerja adalah besarnya perpindahan maksimum struktur saat gempa rencana. Hasil analisa beban dorong statik nonlinear $3 D$ pada struktur Pasar Butung menunjukkan bahwa performance point tercapai pada saat reaksi dasar $V$ sebesar 484,97 ton dengan simpangan sebesar $0,021 \mathrm{~m}(2,1 \mathrm{~cm})$ pada step 3 . Hasil analisa menunjukkan bahwa kinerja struktur masih dalam batas Life Safety

Kata Kunci; Pasar Butung Pasca Kebakaran; Pemeriksaan Lapangan; Pushover; Life Safety

\section{Pendahuluan}

Berbagai penelitian sebelumnya memperlihatkan bahwa adanya penurunan kekuatan pada struktur pasca kebakaran dan tentunya akan diikuti penurunan kapasitas dari struktur tersebut. Komponen struktur seperti kolom, balok, dan pelat akan mengalami penurunan kekuatan pada saat dan setelah terjadi kebakaran. Tingkat kerusakan yang terjadi sangat tergantung pada intensitas api dan durasi kebakaran.

Pada tanggal 15 Desember 2010 telah terjadi kebakaran pada pasar Butung, Makassar. Pasar Butung yang berlokasi di jalan Butung Makassar adalah bangunan yang direncanakan sebagai pasar pusat grosir dan strukturnya didesain sebagai sistem konstruksi beton bertulang biasa. Sehingga muncul pertanyaan sebagai berikut :

1. Bagaimana kekuatan dan kapasitas struktur pasar Butung pasca kebakaran?

2. Bagaimana kinerja struktur pasar Butung pasca kebakaran terhadap beban gempa rencana?

Menjawab pertanyaan tersebut, maka dilakukan penelitian ini dengan tujuan: 
1. Menganalisis kekuatan dan kapasitas struktur pasar Butung pasca kebakaran.

2. Menganalisis kinerja struktur pasar Butung pasca kebakaran.

3. Menentukan metode perbaikan struktur pasar Butung pasca kebakaran.

Pengaruh Temperatur Tinggi terhadap Beton

Temperatur yang terus meningakat akan meyebabkan proses karbonisasi yaitu terbentuknya Kalsium Karbonat (CaCO3) yang berwarna keputih-putihan sehingga mengubah warna permukaan beton menjadi lebih terang (pink keputih-putihan) [1].

Disebutkan dalam [2] bahwa kuat tekan beton akan mengalami penurunan seiring dengan kenaikan temperatur. Pada temperatur $200 \mathrm{oC}$ kekuatan sisa sebesar $95 \%$, pada $400 \mathrm{oC}$ sebesar $62 \%$ dan pada $550 \mathrm{oC}$ sebesar $25 \%$. Penurunan juga terjadi pada modulus elastisitas beton. Pada beton dengan faktor air sebesar 0,6 dan beban statik diperoleh modulus elastisitas sisa $90 \%, 58 \%$ dan $40 \%$ sedangkan pada faktor air semen 0,4 diperoleh sisa $80 \%, 60 \%$ dan $48 \%$ masing-masing pada temperatur $200 \mathrm{oC}, 400 \mathrm{oC}$ dan $550 \mathrm{oC}$.

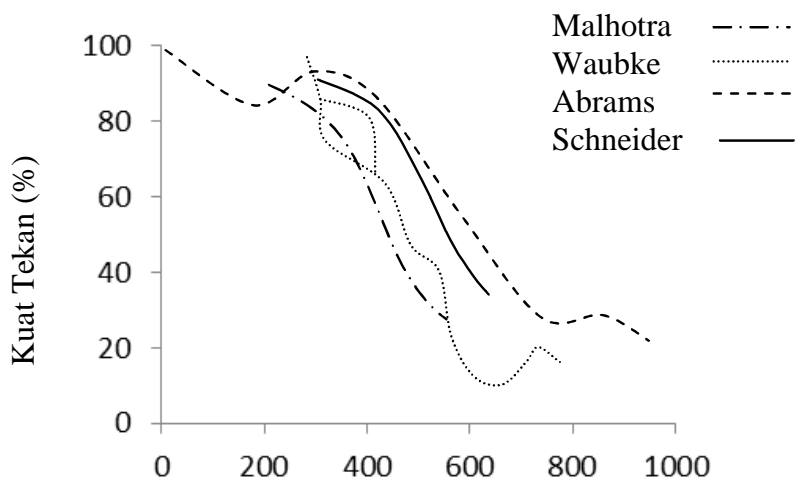

Temperatur $\left({ }^{\circ} \mathrm{C}\right)$

Gambar 1. Kuat tekan beton pada temperatur tinggi [2]

Penelitian [3], menunjuk- kan bahwa kapasitas momen pada balok yang telah terbakar sampai pada temperatur $200 \mathrm{oC}$ mengalami kenaikan sebesar 1,29\% sedangkan pada temperatur $400 \mathrm{oC}$ momen sisa balok sebesar 96,07\%. Demikian halnya dengan frekuensi alami balok pada temperatur $200 \mathrm{oC}$ mengalami kenaikan sebesar $1,92 \%$ sedangkan pada temperatur $400 \mathrm{oC}$ frekuensi alami sisa sebesar $92,31 \%$.

[4] menyatakan bahwa kekuatan beton setelah dingin bervariasi tergantung pada temperatur yang dicapai, lamanya pemanasan, proporsi campuran, aggregat yang digunakan dan beban yang bekerja selama pemanasan. Untuk temperatur sampai pada $300^{\circ} \mathrm{C}$, penurunan kekuatan dari struktur beton tidak signifikan. Pada temperatur diatas $300^{\circ} \mathrm{C}$ akan mulai terjadi penurunan kekuatan secara signifikan. Pada temperatur yang lebih tinggi lagi atau di atas $500^{\circ} \mathrm{C}$ maka beton akan mulai mengalami retak dan hancur (spalling) dengan kuat tekan sisa sudah tidak lagi baik untuk digunakan untuk struktur (sebaiknya dibongkar).

Pengaruh Temperatur Tinggi terhadap Baja Tulangan

Penelitian Ilker. B dan C. Karakurt (2008), menunjukkan bahwa nilai rata-rata hubungan teganganregangan pada baja tulangan jenis S220 dan S420 yang dipanaskan pada berbagai tingkat temperatur kemudian dibiarkan dingin secara alami sampai suhu kamar yaitu pada temperatur dibawah $500^{\circ} \mathrm{C}$ tidak terjadi perubahan yang signifikan pada sifat mekanis baja baik pada tegangan leleh, tegangan ultimit dan regangan maksimumnya.

Pengaruh Lama Kebakaran terhadap Kekuatan Elemen Struktur

Penurunan kekuatan tidak seragam pada seluruh penampang elemen. Bagian terluar dari elemen akan menerima panas yang lebih besar daripada bagian yang lebih dalam. Gambar.2. berikut ini menunjukkan secara skematik bagaimana gradasi temeratur pada suatu penampang kolom dan balok pada saat terjadi kebakaran.

Temperatur yang tercapai selama terjadi kebakaran tergantung pada intensitas kebakaran, durasi kebakaran dan layout bangunan. Pendekatan untuk memperkirakan temperatur yang tercapai selama terjadi kebakaran adalah dengan menggunakan kurva waktu-temperatur 
standar yang terdapat pada ASTM E119 pada Gambar. 3. di dibawah.
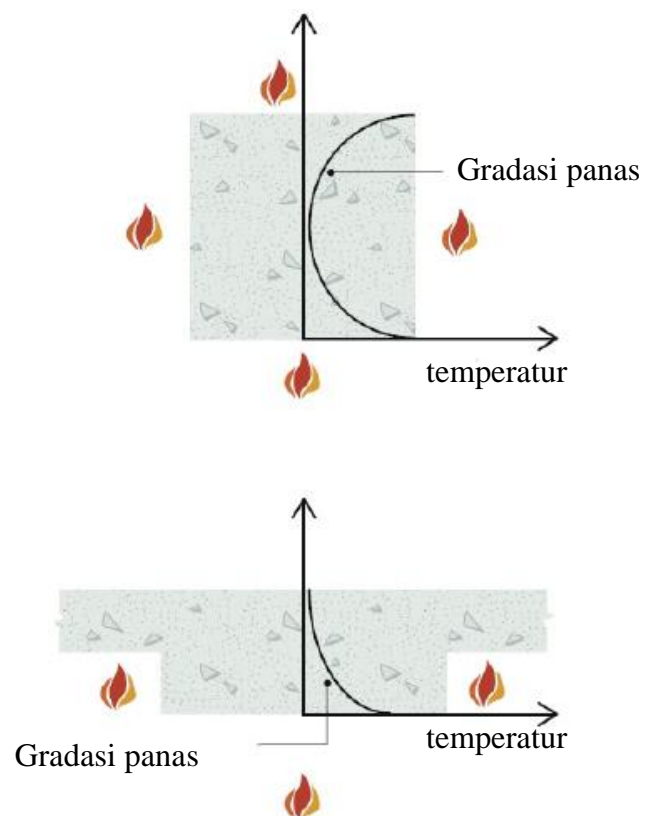

Gambar. 2. Gradasi panas pada penampang kolom dan balok yang terbakar

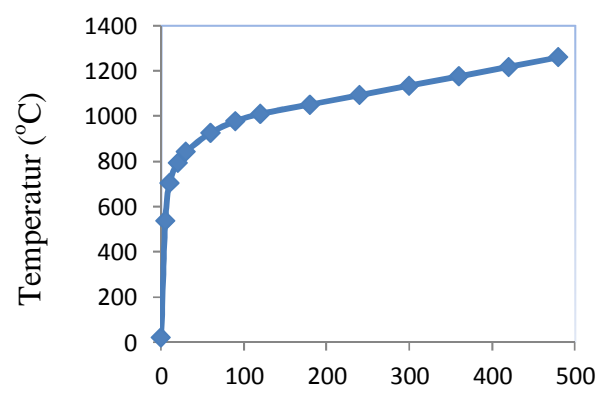

Waktu(Menit)

Gambar. 3. Kurva waktu-temperatur standar (ASTM E119)

\section{Kapasitas Momen Elemen Struktur}

Suatu elemen struktur baik balok, kolom ataupun pelat yang telah terbakar akan mengalami penurunan kapasitas momennya. Seperti yang telah dijelaskan diatas bahwa penurunan kuat tekan penampang balok akan berbeda pada lapisan luar dan dalam akibat adanya perbedaan temperatur dimana sampai pada temperatur $300^{\circ} \mathrm{C}$ belum terjadi penurunan kuat tekan yang signifikan pada beton. Dengan alasan tersebut sehingga penampang elemen struktur akan dibagi menjadi 2 bagian, yaitu 1) bagian penampang yang telah mencapai temperatur diatas $300^{\circ} \mathrm{C}$ dan 2) bagian yang belum mencapai temperatur $300^{\circ} \mathrm{C}$. Kedua bagian tersebut akan dianalisis sebagai sebuah penampang komposit. Bagian penampang yang telah mencapai temperatur diatas $300^{\circ} \mathrm{C}$ akan ditransformasi menjadi penampang yang belum mencapai $300^{\circ} \mathrm{C}$.

Analisa Statik Linear menurut SNI 03-1726-2003

Menurut SNI 03-1726-2003 Pasal 6.1.2, menyatakan bahwa beban geser dasar nominal statik equivalen dapat dihitung dengan persamaan sebagai berikut :

$$
\begin{aligned}
& V=\frac{C . I}{R} . W t \\
& \text { dimana : } \\
& \mathrm{C} \quad=\text { faktor respon gempa berdasarkan } \\
& \quad \text { SNI 03-1726-2003 } \\
& \mathrm{I} \quad=\text { faktor keutamaan } \\
& \mathrm{R} \quad=\text { faktor reduksi Gempa } \\
& \mathrm{Wt} \quad=\text { berat total Struktur }
\end{aligned}
$$

Beban geser dasar nominal V menurut Persamaan. 1. diatas harus dibagikan sepanjang tinggi struktur gedung menjadi beban-beban gempa nominal statik ekuivalen Fi yang menangkap pada pusat massa lantai tingkat ke-i menurut persamaan :

$$
F i=\frac{W i . z i}{\sum W i . z i} \cdot V
$$

dimana :

$$
\begin{array}{ll}
\mathrm{Wi} & =\text { berat lantai ke-i } \\
\mathrm{zi} & =\text { ketinggian lantai tingkat ke-i }
\end{array}
$$

Faktor respon gempa (C) ditentukan berdasarkan grafik respon spektrum pada wilayah gempa yang sesuai. Dalam analisis ini digunakan wilayah gempa 2 (lokasi bangunan di Makassar).

Waktu getar alami fundamental struktur gedung beraturan dalam arah masing-masing sumbu utama dapat ditentukan dengan rumus Rayleigh sebagai berikut : 


$$
T 1=6,3 \sqrt{\frac{\sum_{i}^{n} W i \cdot d i^{2}}{g \cdot \sum_{i}^{n} F i \cdot d i}}
$$

dimana :

$d i=$ simpangan horisontal lantai tingkat ke- $\mathrm{i}$

$\mathrm{g}=\operatorname{gravitasi}(9810 \mathrm{~m} /$ detik $)$

Analisa Dinamik Linear menurut SNI 03-1726-2003

Menurut SNI 1726-2003, perhitungan respon dinamaik struktur tidak beraturan terhadap pembebanan gempa nominal akibat pengaruh gempa rencana dapat dilakukan dengan metode ragam spektrum respon dengan memakai metode Spektrum Respon Gempa Rencana menurut SNI-03-1726-2003 dibuat berdasarkan percepatan puncak batuan dasar akibat pengaruh gempa rencana dengan periode ulang 500 tahun. Menurut SNI 1726-2003, nilai akhir respon dinamik struktur gedung terhadap pembebanan gempa nominal akibat pengruh gempa rencana dalam suatu arah tertentu, tidak boleh diambil kurang dari $80 \%$ nilai respon ragam yang petama. Bila respon dinamik struktur gedung dinyatakan dalam gaya geser dasar nominal $\mathrm{V}$, maka persyaratan tersebut dapat dinyatakan menurut persamaan berikut:

$$
\mathrm{V} 1>0,8 \mathrm{Vi}
$$

Dimana gaya Vi adalah gaya geser dasar nominal sebagai respon ragam yang pertama terhadap pengaruh gempa rencana menurut Persamaan (1).

Tingkat kinerja struktur (Performance Level)

1. Operation / Operasi. Pada level ini bangunan dapat berfungsi dengan baik, tidak terdapat kerusakan berarti pada komponen struktural maupun nonstruktural.

2. Immediate Occupancy (IO) / Segera difungsikan. Ditandai dengan kerusakan kecil pada struktur bangunan. Resiko korban jiwa sangat rendah dan mungkin dibutuhkan sedikit perbaikan pada struktur akan tetapi secara umum bangunan dapat segera digunakan kembali.

3. Life Safety $(L S)$ / Keselamatan pengguna. Ditandai dengan adanya kerusakan yang cukup signifikan pada struktur, tetapi tidak mengalami keruntuhan parsial ataupun total. Korban jiwa mungkin ada akan tetapi dalam jumlah yang sedikit. Struktur tetap bisa diperbaiki walaupun secara ekonomi mungkin tidak menguntungkan.

4. Collaps Prevention (CP) / Diambang keruntuhan. Ditandai dengan adanya kerusakan yang parah pada struktur. Setelah terjadi gempa, struktur berada diambang keruntuhan baik sebagian ataupun keseluruhan. Bagaimanapun, struktur harus tetap mampu menahan beban gravitasi. Korban jiwa yang cukup signifikan akibat reruntuhan puing bangunan. Pada level ini struktur tidak memungkinkan lagi untuk diperbaiki.

Adapun tingkat kinerja bangunan dapat ditampilkan dalam suatu skema hubungan gaya lateral dengan deformasi lateral seperti pada Gambar. 6. Notasi A, B, IO, LS, CP, C, D dan E adalah titik kontrol perpindahan yang memberikan informasi kinerja struktur.

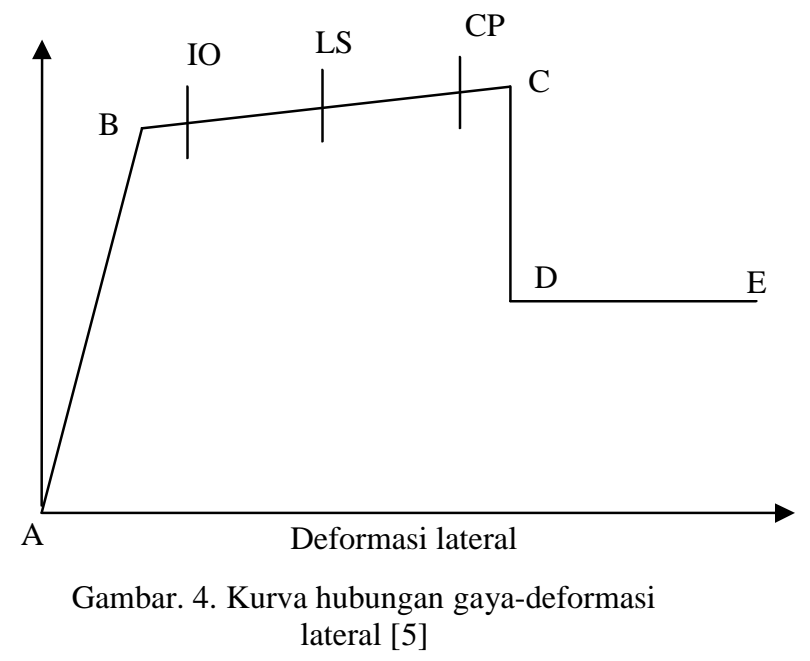

Pada interval B ke C, terdapat titik-titik IO, LS dan $\mathrm{CP}$ yang menyatakan tingkat kinerja dari struktur tersebut. Nilai-nilai dari titik-titik tersebut terdapat di dalam FEMA 356, yang merupakan panduan dalam analisis non linear.

\section{Simpangan Struktur (Structural Drift)}

Simpangan struktur (structural drift) adalah perbandingan antara pergeseran suatu titik acuan pada struktur (biasanya pada atap) terhadap tinggi bangunan. 
Nilai simpangan sangat erat hubungannya dengan kinerja struktur.

$$
D R=\frac{d}{H} x 100 \%
$$

dimana :

$$
\begin{aligned}
\mathrm{DR} & =\operatorname{drift} \text { ratio }(\%) \\
\mathrm{d} & =\operatorname{simpangan} \operatorname{atap}(\mathrm{m}) \\
\mathrm{H} & =\text { tinggi bangunan }(\mathrm{m})
\end{aligned}
$$

Dalam FEMA 356, nilai rasio simpangan struktur ditunjukkan pada Tabel. 1. dimana nilai maksimum adalah 4\% untuk kondisi Collapse Prevention (CP).

\section{Spektrum Kapasitas}

Dalam metode spektrum kapasitas memperlihatkan dua buah spektrum yaitu spektrum kapasitas dan spektrum demand. Spektrum kapasitas (capacity spectrum) adalah hubungan antara gaya dorong dasar total (base shear) dengan perpindahan lateral struktur (biasanya diukur pada puncak bangunan).

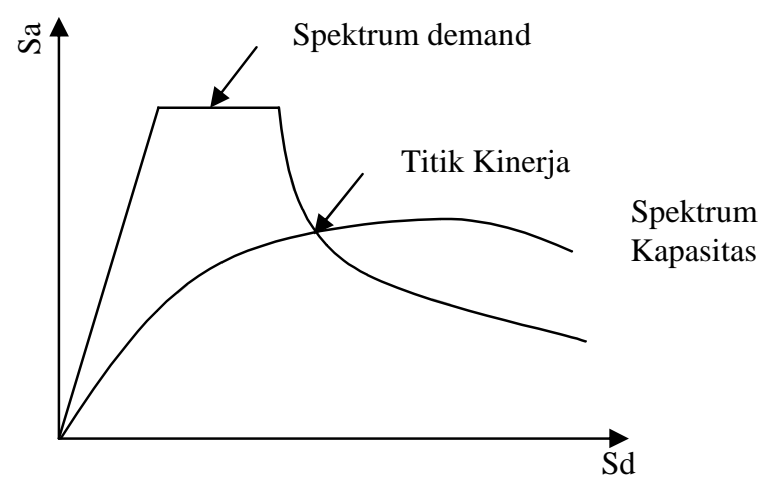

Gambar. 5. Titik kinerja struktur gedung [6]

Spektrum kapasitas diperoleh dari kurva kapasitas dari analisa pushover. Untuk mendapatkan titik kinerja (performance point), kurva kapasitas harus diubah menjadi spektrum kapasitas dengan format spektral percepatan, $\mathrm{Sa}$, dan spektral perpindahan, $\mathrm{Sd}$, yang biasa disebut Acceleration-Displacement Respon Spectra (ADRS). Perpotongan kedua spektrum tersebut memberikan titik kinerja struktur saat menerima beban gempa rencana.

\section{Metode Penelitian}

Penelitian dimulai dengan pengambilan data mengenai kronologis, durasi, dan pusat terjadinya kebakaran.

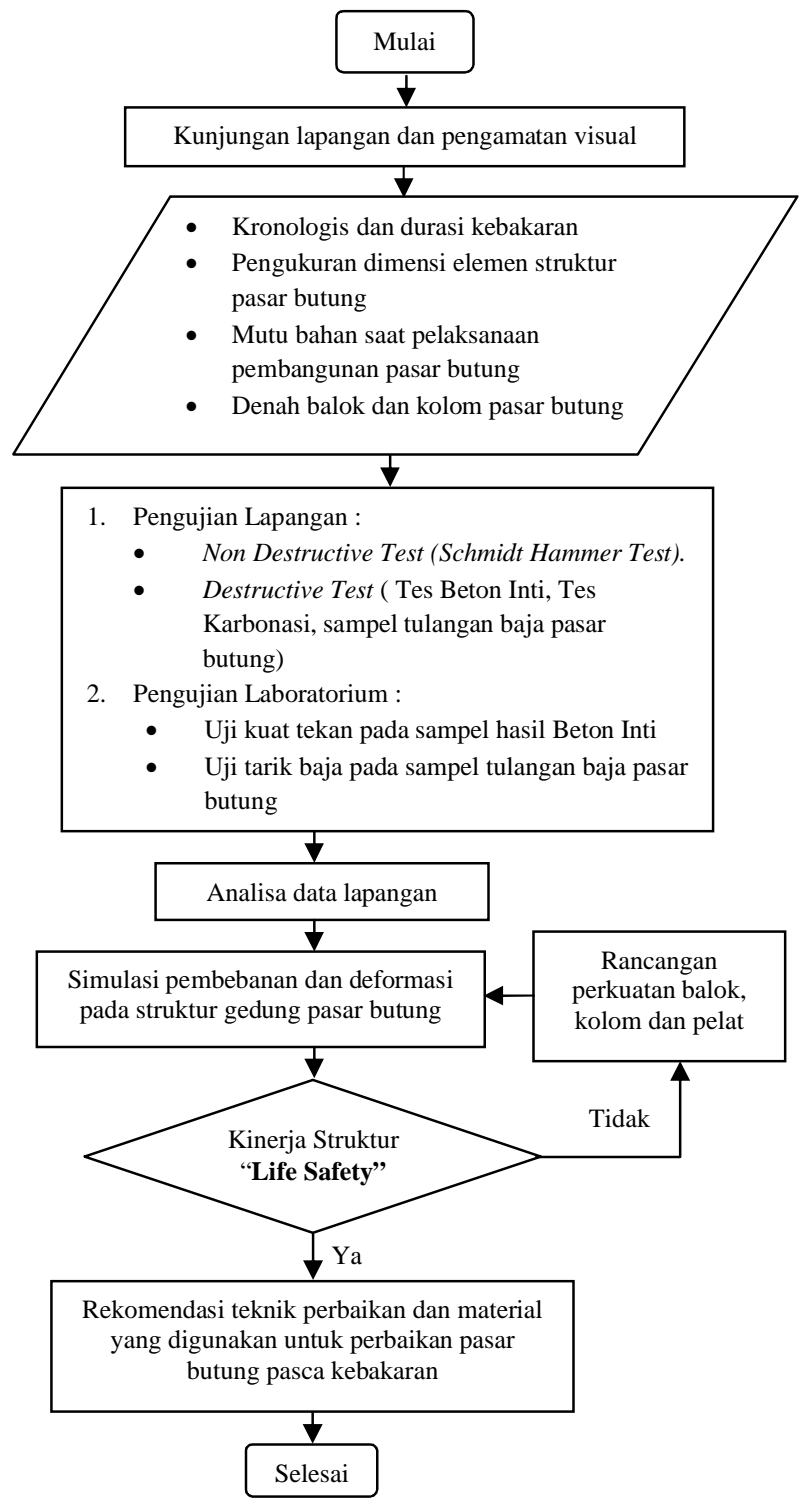

Gambar. 6. Bagan alir penelitian

Data tersebut diperoleh dari pihak pengelola pasar yang merupakan penanggungjawab kegiatan di pasar Butung. Penelitian dilanjutkan dengan pengujian lapangan yang mencakup pengamatan visual, pengujian 
karbonasi, pengujian alat palu beton, pengujian beton inti dan pengujian kuat tarik baja tulangan. Hasil pengujian akan menjadi dasar dalam analisa struktur sebagai input dalam perhitungan dalam proram komputer yang digunakan dalam analisis.

\section{Hasil dan Pembahasan}

\section{Pengamatan Visual}

Seluruh elemen struktur pada lantai 1 dan 2 telah mengalami retak rambut. Pada beberapa balok anak telah mengalami retak lebar sampai $1,5 \mathrm{~cm}$ dan lendutan mencapai $5 \mathrm{~cm}$. Elemen struktur pada lantai 3 dan 4 secara umum tidak mengalami kerusakan yang berarti dimana retak rambut hanya terjadi pada permukaan plesteran dan tidak sampai pada elemen di dalamnya serta tidak terjadi lendutan.

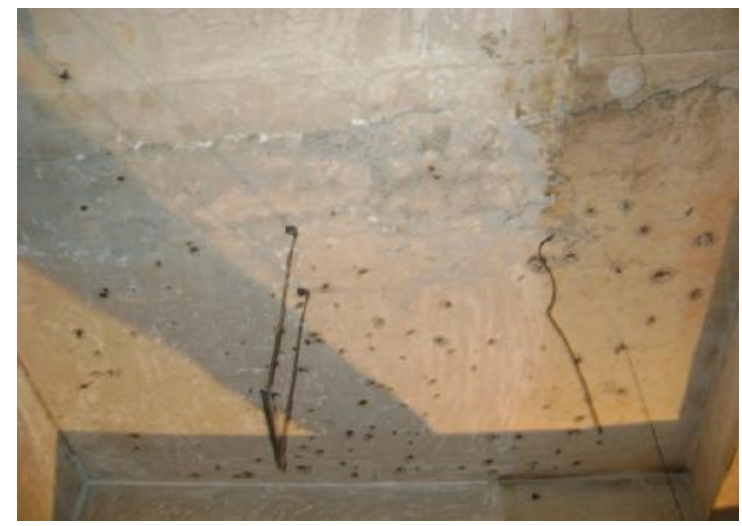

Gambar. 7. Kondisi pelat lantai 2 pasca kebakaran

Berdasarkan hasil pengamatan visual dimana terlihat bahwa terjadi perubahan warna beton menjadi putih dan keabu-abuan dapat kita simpulkan bahwa temperatur yang tercapai pada saat terjadi kebakaran pada lantai 1 dan 2 adalah sekitar $400^{\circ} \mathrm{C}$, sehingga kuat tekan beton sisa dapat diperkirakan dengan menggunakan kurva hubungan kuat tekan beton - temperatur pada Gambar. 2. dimana dapat diperkirakan bahwa kuat tekan sisa beton adalah $62 \%$ terhadap kuat tekan awalnya. Kuat tekan awal beton berdasarkan keterangan dari pihak kotraktor adalah K250, sehingga kuat tekan beton sisa dapat dihitung sebagai berikut:

$$
\begin{gathered}
f^{\prime} \operatorname{csisa}(\text { teor } i)=62 \% \times 250 \mathrm{~kg} / \mathrm{cm}^{2} \\
=155 \mathrm{~kg} / \mathrm{cm}^{2}
\end{gathered}
$$

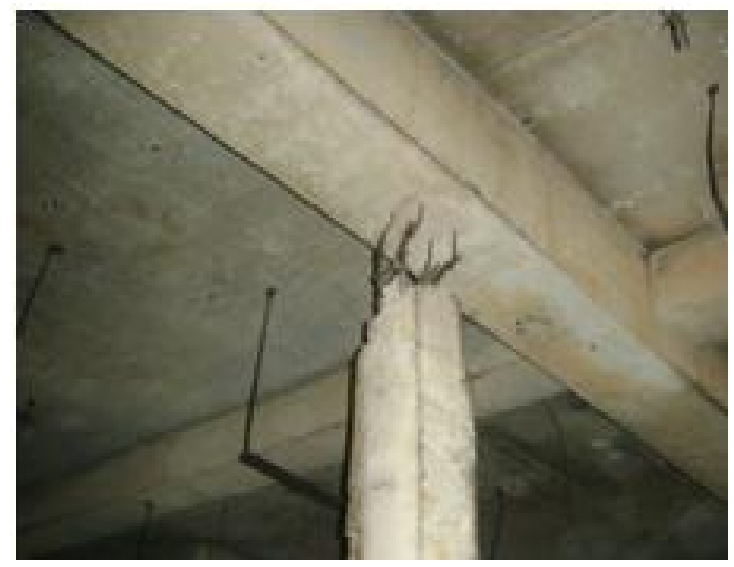

Gambar. 8. Kondisi balok dan kolom praktis lantai 1 pasca kebakaran

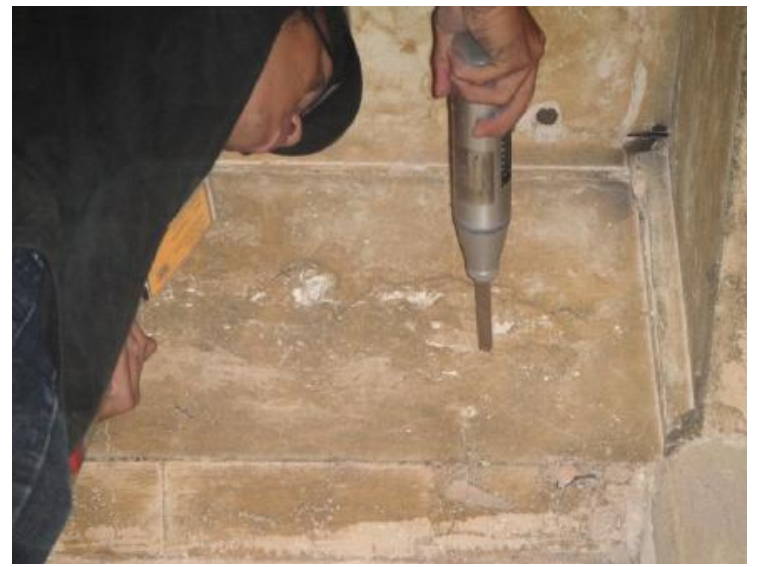

Gambar. 9. Pengujian alat palu beton tipe $\mathrm{N}$

\section{Pengujian Alat Palu Beton}

Kuat tekan rata-rata pada kolom dan balok lantai 1 dan 2 diperkirakan adalah $14 \mathrm{MPa}$. Untuk kolom dan balok pada lantai 3 dan 4 diperkirakan adalah $20 \mathrm{MPa}$. Untuk balok anak dan pelat lantai 1 dan 2 diperkirakan adalah $12 \mathrm{MPa}$. Sedangkan untuk balok anak dan pelat lantai 3 dan 4 diperkirakan adalah $20 \mathrm{MPa}$. Hasil pengujian alat palu beton menjadi dasar dalam analisis dan pemodelan struktur pada software yang digunakan karena data ini dianggap dapat mewakili nilai kuat tekan sisa. 


\section{Pengujian Beton Inti}

Kuat tekan sisa beton diukur secara langsung dengan menggunakan benda uji beton inti. Sampel beton inti diambil pada pelat lantai 2 dan 3. Sampel beton inti hanya memungkinkan untuk diambil pada pelat lantai karena tidak terdapat balok ataupun kolom yang dibongkar untuk diambil sampel beton ini. Sampel pengujian beton inti memiliki diameter rata-rata $70 \mathrm{~mm}$. Sampel benda uji yang telah diambil kemudian diuji di laboratorium. Hasil pengujian pada tiga sampel beton inti menunjukkan bahwa kuat tekan beton rata-rata 11,57 $\mathrm{N} / \mathrm{mm} 2$, yang berarti telah mengalami penurunan sebesar $45,30 \%$ dari kuat tekan awalnya.

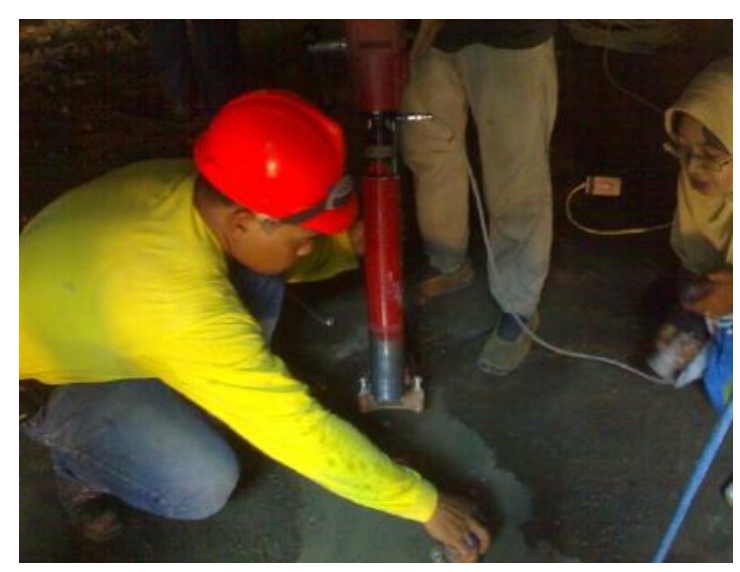

Gambar. 10. Pengambilan sampel beton inti

\section{Pengujian Karbonasi}

Hasil pengujian karbonasi pada seluruh elemen struktur diperoleh bahwa rata-ratakarbonasi pada elemen kolom lantai 1 dan 2 belum terjadi sampai pada kedalaman 0,5 - $1 \mathrm{~cm}$ dan pada lantai 3 dan 4 sampai kedalaman 0,3-0,5 cm. Pada elemen balok lantai 1 dan 2 karbonasi belum terjadi sampai pada kedalaman 0,5 - 1 cm dan pada lantai 3 dan 4 sampai kedalaman $0,3-0,5$ $\mathrm{cm}$. Sedangkan untuk elemen pelat pada lantai 2 dan 3 karbonasi pada bagian yang retak lebar atau lebih dari $2,5 \mathrm{~cm}$ dan pada bagian yang tidak retak sampai kedalaman $0,5-1,5 \mathrm{~cm}$.
Tabel. 2. Perbandingan kuat tekan beton sisa pasca kebakaran

\begin{tabular}{lcccc}
\hline \multirow{2}{*}{$\begin{array}{c}\text { Elemen } \\
\text { Struktur }\end{array}$} & $\begin{array}{c}\text { Kuat } \\
\text { tekan } \\
\text { awal }\end{array}$ & Teori & $\begin{array}{c}\text { Alat } \\
\text { Palu } \\
\text { Beton }\end{array}$ & $\begin{array}{c}\text { Beton } \\
\text { Inti }\end{array}$ \\
\hline $\begin{array}{l}\text { Kolom dan } \\
\text { balok lt 1-2 }\end{array}$ & 21,15 & 13,11 & 14 & - \\
\hline Pelat 1t 2-3 & 21,15 & 13,11 & 14 & 11,57 \\
\hline $\begin{array}{l}\text { Kolom dan } \\
\text { balok lt 3-4 }\end{array}$ & 21,15 & 21,15 & 20 & - \\
\hline Pelat lt 4-atap & 21,15 & 21,15 & 20 & - \\
\hline
\end{tabular}

Pengujian Kuat Tarik Baja Tulangan

Hasil pengujian memperlihatkan bahwa baja tulangan diameter $8 \mathrm{~mm}$ dan $10 \mathrm{~mm}$ memiliki kuat leleh masingmasing 384,996 MPa dan 320,412 MPa. Dari hasil pengujian baja tulangan dapat disimpulkan bahwa baja tulangan yang ada didalam struktur secara umum masih baik dan memiliki kekuatan yang cukup tinggi yaitu masih diatas $300 \mathrm{MPa}$. Berdasarkan data hasil pengujian diatas maka dalam analisa struktur digunakan mutu beton 14 dan $20 \mathrm{MPa}$.

Kapasitas momen elemen struktur

Kapasitas momen balok

Berdasarkan data hasil pengujian diatas dengan menggunakan nilai kuat tekan sisa sebesar 14 MPa pada bagian penampang terluar beton dan mutu baja sisa sebesar $320 \mathrm{MPa}$, maka kapasitas momen balok dapat dihitung seperti pada tabel berikut ini :

Kapasitas momen kolom

Dengan menggunakan data hasil pengujian yang sama dengan data pada perhitungan balok diatas maka kapasitas momen kolom dapat dihitung seperti pada tabel berikut ini : 
Tabel. 3. Tabel perbandingan kapasitas momen balok pasca kebakaran

\begin{tabular}{lccc}
\hline $\begin{array}{c}\text { Elemen } \\
\text { struktur }\end{array}$ & A & B & C \\
\hline Balok B1 & & & \\
Tumpuan & 326,09 & 306,43 & $93,97 \%$ \\
Lapangan & 341,46 & 319,31 & $93,51 \%$ \\
\hline Balok B2 & & & \\
Tumpuan & 220,17 & 207,04 & $94,03 \%$ \\
Lapangan & 177,06 & 166,44 & $94,01 \%$ \\
\hline Balok Ba & & & \\
Tumpuan & 127,37 & 119,64 & $93,93 \%$ \\
Lapangan & 96,05 & 91,77 & $95,54 \%$ \\
\hline
\end{tabular}

Tabel. 4. Tabel perbandingan kapasitas momen kolom pasca kebakaran

\begin{tabular}{llcc}
\hline $\begin{array}{l}\text { Elemen } \\
\text { struktur }\end{array}$ & A & B & C \\
\hline Kolom K1 & & & \\
$\mathrm{Pu}$ & 962,70 & 890,27 & $92,48 \%$ \\
$\mathrm{Mu}$ & 191,76 & 177,30 & $92,46 \%$ \\
\hline $\mathrm{Kolom} \mathrm{K2}$ & & & \\
$\mathrm{Pu}$ & 962,70 & 890,27 & $92,48 \%$ \\
$\mathrm{Mu}$ & 159,45 & 146,89 & $92,12 \%$ \\
\hline
\end{tabular}

dimana :

$$
\begin{aligned}
& \mathrm{A}=\text { kapasitas momen awal }(\mathrm{KN} . \mathrm{m}) \\
& \mathrm{B}=\text { kapasitas momen pasca kebakaran }(\mathrm{KN} . \mathrm{m}) \\
& \mathrm{C}=\text { persentase momen sisa }
\end{aligned}
$$

\section{Analisa Struktur}

1. Perhitungan berat total bangunan dengan bantuan software.

Perhitungan berat total struktur dapat dilihat pada tabel 5.

2. Waktu getar alami fundamental bangunan

$$
\begin{aligned}
& \mathrm{T}_{1}=\xi \cdot \mathrm{H}_{\mathrm{n}}{ }^{3 / 4} \\
\mathrm{~T}_{1}= & 0,102 \times 19,00^{3 / 4} \quad=0,928 \mathrm{dtk}
\end{aligned}
$$

Tabel. 5. Berat bangunan hasil perhitungan

\begin{tabular}{cccc}
\hline Lantai & $\begin{array}{c}\text { Beban } \\
\text { Hidup }\end{array}$ & $\begin{array}{c}\text { Beban } \\
\text { Mati }\end{array}$ & $\begin{array}{c}\text { DL }+30 \% \\
\text { LL }\end{array}$ \\
\hline Atap & 348.000 & 2.160 .458 & 2.265 .039 \\
\hline Lantai 4 & 1.006 .500 & 3.325 .372 & 3.627 .322 \\
\hline Lantai 3 & 1.209 .000 & 3.678 .084 & 4.040 .785 \\
\hline Lantai 2 & 1.209 .000 & 3.825 .089 & 4.187 .789 \\
\hline Lantai 1 & 871.5000 & 2.833 .247 & 3.094 .697 \\
\hline & & TOTAL & 17.215 .631 \\
\hline
\end{tabular}

\section{Koefisien gempa dasar}

Dari tabel 6 spektrum respon gempa rencana (SNI 03-1726-2003) diperoleh :

$\mathrm{C}=0,23 / 0,928=0,248$

\section{Faktor keutamaan I}

Berdasarkan desain struktur rangka beton di daerah rawan gempa (SNI 03-1726-2003 pasal 4.2) Tabel. 1 diperoleh faktor keutamaan $\mathrm{I}=1,0$ untuk gedung umum seperti untuk penghunian, perniagaan, dan perkantoran.

\section{Faktor Reduksi Gempa (R)}

Berdasarkan taraf kinerja struktur di daerah rawan gempa (SNI 03-1726-2003 pasal 4.4.4) tabel 2 dengan asumsi struktur adalah daktail parsial, untuk $\mu=2,1$ maka diperoleh nilai $\mathrm{R}=3,5$ (struktur berada pada wilayah gempa 2 dikategorikan SRPMB)

6. Gaya geser horizontal total akibat gempa

$$
\begin{aligned}
\text { Vtotal } \quad=\mathrm{Vx} & =\mathrm{Vy}=(\mathrm{C} . \mathrm{I} . \mathrm{Wt}) / \mathrm{R} \\
& =1.218,76 \text { ton }
\end{aligned}
$$

7. Distribusi gaya geser hotizontal total.

Distribusi gaya geser horizontal total bangunan berdasarkanhasil perhitungan dapat dilihat pada tabel 6 berikut. 
Tabel. 6. Gaya gempa statik ekuivalen

\begin{tabular}{ccc}
\hline Tingkat & $\begin{array}{c}\text { Fix,Fiy } \\
\text { total }\end{array}$ & 30\% Fix.Fiy \\
\hline Atap & 283,66 & 118,74 \\
\hline 4 & 362,21 & 151,62 \\
\hline 3 & 300,96 & 125,98 \\
\hline 2 & 205,64 & 86,08 \\
\hline 1 & 66,29 & 27,75 \\
\hline & $1.218,76$ & 365,63 \\
\hline
\end{tabular}

8. Eksentrisitas Pusat Massa Terhadap Pusat Rotasi

Untuk $0<\mathrm{e}, 0,3 \mathrm{~b}$ :

$\mathrm{Ed}=1,5 \mathrm{e}+0,05 \mathrm{~b}$ atau ed $=\mathrm{e}-0.005 \mathrm{~b}$

Untuk e >0,3 b :

$\mathrm{Ed}=1,33 \mathrm{e}+0,1$ atau $\mathrm{ed}=1,17 \mathrm{e}-0,1 \mathrm{~b}$

dimana :

$\mathrm{b}=$ ukuran horizontal terbesar pada lantai gedung yang ditinjau

$\mathrm{e}=$ selisih antara pusat massa dan pusat kekakuan pada lantai yang ditinjau.

Tabel. 7. Eksentrisitas arah $\mathrm{X}$

\begin{tabular}{ccccl}
\hline Lantai & XCM & XCR & $\mathrm{e}_{\mathrm{d}}$ & $\mathrm{x}-\mathrm{kr}$ \\
\hline Atap & 43,500 & 43,501 & 4,352 & 39,149 \\
\hline 4 & 43,500 & 43,501 & 4,352 & 39,149 \\
\hline 3 & 43,500 & 43,501 & 4,352 & 39,149 \\
\hline 2 & 43,511 & 43,501 & 4,365 & 39,146 \\
\hline 1 & 43,508 & 43,501 & 4,361 & 39,148 \\
\hline
\end{tabular}

Tabel. 8. Eksentrisitas arah $\mathrm{Y}$

\begin{tabular}{ccccc}
\hline Lantai & YCM & YCR & $\mathrm{e}_{\mathrm{d}}$ & $\mathrm{y}-\mathrm{kr}$ \\
\hline Atap & 32,518 & 31,070 & 4,573 & 27,945 \\
\hline 4 & 30,689 & 31,087 & 3,722 & 26,967 \\
\hline 3 & 30,465 & 31,090 & 4,063 & 26,403 \\
\hline 2 & 30,642 & 31,094 & 3,803 & 26,839 \\
\hline 1 & 30,682 & 31,446 & 4,271 & 26,411 \\
\hline
\end{tabular}

9. Analisa waktu getar struktur dengan cara $\mathrm{T}_{\text {Rayleigh }}$

$$
T_{\text {Fioloigh }}=6.3 \sqrt{\frac{216.849,66}{981 \times 4 . / 43, / 03}}=1,360
$$

Maka yang diambil adalah $\mathrm{T}_{\text {Reyleigh }}=1,360$ yang menghasilkan $\mathrm{C}=0,23 / 1,360=0,169$ sehingga perhitungan diatas diulang.

$$
\begin{aligned}
& \text { Vtotal }=\mathrm{Vx}=\mathrm{Vy}=(\mathrm{C} . \mathrm{I} \cdot \mathrm{Wt}) / \mathrm{R} \\
& \quad=(0,169 \times 1 \times 17.215 \cdot 631) / 3,5 \\
& \quad=831,91 \text { ton }
\end{aligned}
$$

10. Kinerja batas layan $\Delta \mathrm{s}$

Tabel. 9. Simpangan struktur arah $\mathrm{X}$

\begin{tabular}{ccccc}
\hline Tingkat & $\begin{array}{c}\mathrm{Hi} \\
(\mathrm{m})\end{array}$ & $\begin{array}{c}\Delta \mathrm{s} \\
(\mathrm{cm})\end{array}$ & Syarat & Keterangan \\
\hline Atap & 3,85 & 0,370 & 3,000 & memenuhi \\
\hline 4 & 3,85 & 0,670 & 3,000 & memenuhi \\
\hline 3 & 3,85 & 0,990 & 3,000 & memenuhi \\
\hline 2 & 4,20 & 1,310 & 3,000 & memenuhi \\
\hline 1 & 3,25 & 0,000 & 2,786 & memenuhi \\
\hline
\end{tabular}

Tabel. 10. Simpangan struktur arah Y

\begin{tabular}{ccccc}
\hline Tingkat & $\begin{array}{c}\mathrm{Hi} \\
(\mathrm{m})\end{array}$ & $\begin{array}{c}\Delta \mathrm{s} \\
(\mathrm{cm})\end{array}$ & Syarat & Keterangan \\
\hline Atap & 3,85 & 0,380 & 3,000 & memenuhi \\
\hline 4 & 3,85 & 0,720 & 3,000 & memenuhi \\
\hline 3 & 3,85 & 1,070 & 3,000 & memenuhi \\
\hline 2 & 4,20 & 1,430 & 3,000 & memenuhi \\
\hline 1 & 3,25 & 0,000 & 2,786 & memenuhi \\
\hline
\end{tabular}

11. Evaluasi gempa

Ty $=1,041 \mathrm{dtk}$ syarat bangunan $\mathrm{T}_{\max }$ adalah 0,928 dtk, jadi dipakai $\mathrm{T}_{1 \max }$ dari tabel kurva spektrum gempa wilayah 2 tanah sedang maka

$$
\begin{aligned}
\mathrm{C}_{1} & =0,23 / 0,928=0,248 \\
\mathrm{Vy}_{\mathrm{y}} & =(\mathrm{C} \times \mathrm{I} \times \mathrm{Wt}) / \mathrm{R} \\
& =(0,248 \times 1 \times(17.047,04+0,3 \times 4.982,10) / 3,5 \\
& =1.312,63 \text { ton }
\end{aligned}
$$

$$
0,8(\mathrm{Vx})=1.050,11 \text { ton }
$$$$
\mathrm{V} \text { rsp y }=280,67 \text { ton }
$$

$$
F S-\frac{0,8 V y}{V r s p y}-\frac{1,050,11}{280,67}-3,74
$$


Tabel. 11. Simpangan struktur arah X

\begin{tabular}{cccc}
\hline Tingkat & $\begin{array}{c}\text { Gaya } \\
\text { Lateral }\end{array}$ & $\begin{array}{c}\text { Jumlah } \\
\text { Node }\end{array}$ & $\begin{array}{c}\text { Gaya } \\
\text { (ton) }\end{array}$ \\
\hline Atap & 536,1439 & 132 & 4,062 \\
\hline 4 & 563,1257 & 186 & 3,028 \\
\hline 3 & 421,1921 & 186 & 2,264 \\
\hline 2 & 277,9342 & 186 & 1,494 \\
\hline 1 & 250,39 & 186 & 1,346 \\
\hline
\end{tabular}

\section{Hasil Analisa Pushover}

Kurva pushover dari hasil analisa seperti pada Gambar. 13. berhenti pada langkah (step) 5, yaitu pada saat simpangan pada titik kontrol tercatat sebesar $0,0664 \mathrm{~m}(6,64 \mathrm{~cm})$ dan gaya geser dasar sebesar 870,0227 ton. Berdasarkan Gambar. 14. Berikut ini diperoleh bahwa performance point berdasarkan ATC-40 pada arah pembebanan sumbu utama Y (sumbu lemah) tercapai pada saat reaksi dasar V sebesar 484,97 ton dan dengan simpangan sebesar $0,021 \mathrm{~m}(2,1 \mathrm{~cm})$. Performance point tercapai pada step 3 dimana 103 elemen telah melewati batas IO (Immediate Occupancy), namun belum ada elemen yang telah melewati batas LS (Life Safety), dan CP (Collapse Prevention). Level kinerja struktur (Structure performance levels) dapat ditentukan melalui kriteria rasio simpangan struktur (structural-drift ratio) yang diperoleh saat titik kinerja tercapai. Hasil perhitungan tersebut kemudian dibandingkan dengan persyaratan simpangan (drift) yang terdapat di dalam FEMA 356 (2000) [7] pada Tabel. 2 untuk menentukan level kinerja struktur tersebut.

Rasio simpangan struktur adalah perbandingan antara simpangan titik kontrol dengan elevasi titik kontrol tersebut. Dari hasil analisa pushover diperoleh bahwa simpangan titik kontrol saat tercapai performance point sebesar 0,021 m sedangkan elevasinya adalah $19 \mathrm{~m}$, sehingga rasio simpangan struktur dapat dihitung sebagai berikut :

$$
D R=\left(\frac{0,021}{19}\right) \times 100 \%=0,11 \%
$$

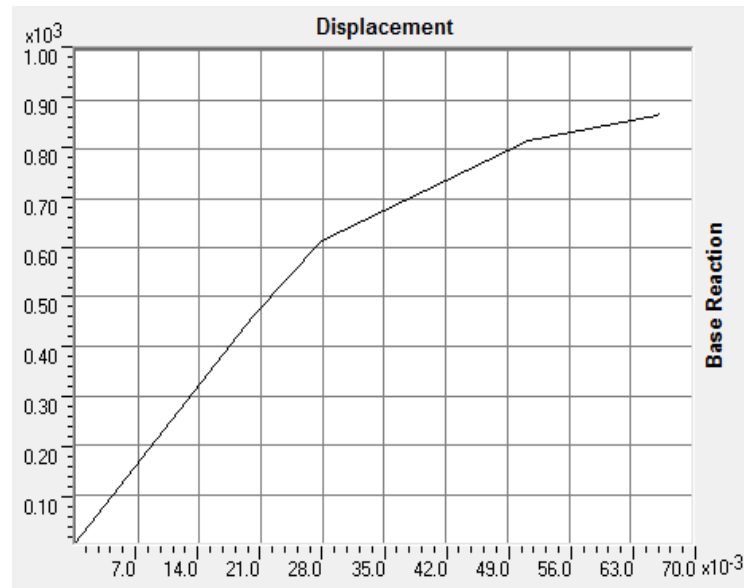

Gambar. 11. Kurva hubungan base shear displacement

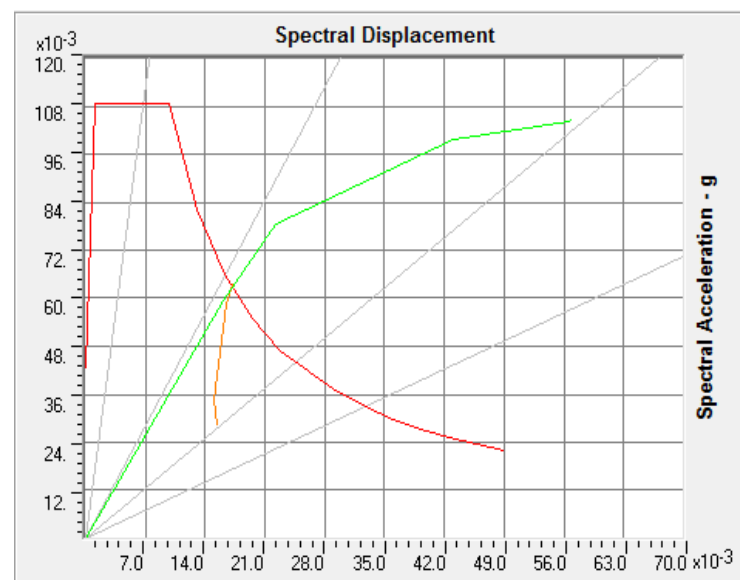

Gambar. 12. Titik kinerja struktur (performance

point)

Berdasarkan nilai rasio simpangan struktur diatas dapat disimpulkan bahwa level kinerja struktur adalah Immediate Occupancy (IO). Hal ini karena rasio simpangan struktur yang terjadi masih lebih kecil dari nilai yang disyaratkan oleh FEMA 356 yaitu $1 \%$. Level kinerja yang disyaratan untuk bangunan permukiman, perkantoran dan perniagaan adalah Life Safety. Sehingga level kinerja bangunan Pasar Butung pasca kebakaran apabila menerima beban gempa rencana memenuhi persyaratan yaitu masih dalam batas Life Safety. Hal ini berarti bangunan struktur pasar butung dapat 
mempertahankan stabilitasnya saat menerima beban gempa rencana.

\section{Metode Perbaikan Struktur Pasca Kebakaran}

1. Pelat yang rusak parah (retak $>10 \mathrm{~mm}$ ) dibongkar lalu dicor ulang dengan mempertahanakan tulangan yang ada.

2. Pelat yang retak $<10 \mathrm{~mm}$ dapat di-grouting.

3. Elemen kolom dan balok yang mengalami retak rambut dan terkelupas lapisan plesterannya diperbaiki dengan melakukan finishing berupa plesteran ulang.

4. Untuk elemen nonstruktural seperti dinding partisi, plafon dan finishing ME harus dibongkar dan dibuat ulang.

\section{Kesimpulan}

Dari hasil penelitian ini dapat ditarik kesimpulan sebagai berikut :

1. Berdasarkan hasil analisa beban dorong statik equivalen nonlinear (Static Nonlinear Pushover Analysis) diperoleh bahwa performance point tercapai pada saat reaksi dasar V sebesar 484,97 ton dengan simpangan sebesar $0,021 \mathrm{~m}(2,1 \mathrm{~cm})$. Performance point ini tercapai pada step 3 .

2. Berdasarkan hasil analisa beban dorong statik nonlinear (Static Nonlinear Pushover Analysis) diperoleh bahwa kinerja struktur Pasar Butung pasca kebakaran masih dalam batasan Life Safety (LS).
3. Perbaikan struktur pasar Butung pasca kebakaran hanya berupa perbaikan minor pada balok dan kolom, sedangkan untuk pelat dengan retak $>10 \mathrm{~mm}$ dibongkar lalu dicor ulang.

\section{Ucapan Terima Kasih}

Dari pihak penulis mengucapkan banyak terima kasih kepada PD Pasar Sentral yang telah memberikan kami kesempatan untuk melakukan pengambilan data lapangan sehingga penelitian ini dapat kami rampungkan. Kepada teman-teman mahasiswa S2 Teknik Sipil Universitas Hasanuddin yang tak hentihentinya membantu kami sehingga tulisan ini dapat dirampungkan.

\section{Daftar Pustaka}

[1] Wei, M.L, Microstructure of Fire-Damaged Concrete, Aci Materials Journal Volume 3, No 3, Detroi, 1996.

[2] Malhotra H. L., Design of Fire Resisting Structure, Surrey University Press, New York, 1982.

[3] Irma, Kapastas Sisa Balok Pasca Bakar, Thesis Universitas Gadjah Mada, Yogyakarta, 2000.

[4] Ingham J, Forensic Engineering of Fire-Damaged Structure, Proceedings of ICE, London, 2009.

[5] ACI Committee 318, Building Code Requirements For Structural Concrete (ACI 318-2005) and Commentary (ACI 318R - 2005). American Concrete Institute, Detroi, 2005.

[6] ATC-40, Seismic Evaluation and Retrofit of Concrete Buildings, Applied Technology Council. Redwood City: California, 1996.

[7] FEMA 356, Seismic Rehabilitation Prestandard, American Society of Civil Engineers for the Federal Emergency Management Agency, Washington, D.C. 